\title{
The Impact of Turning Jordan into an Economic Free Zone on the Flow of Foreign Investments
}

\author{
Ahmad Y. Areiqat ${ }^{1} \&$ Hanan Ibrahim $^{1}$ \\ ${ }^{1}$ Business School, Al-Ahliyya Amman University, Amman, Jordan \\ Correspondence: Ahmad Y. Areiqat, Business School, Al-Ahliyya Amman University, Amman, Jordan. E-mail: \\ ahmadareiqat@ammanu.edu.jo
}

Received: September 25, 2018

Accepted: October 26, 2018

Online Published: November 12, 2018

doi:10.5539/ijbm.v13n12p61

URL: https://doi.org/10.5539/ijbm.v13n12p61

\begin{abstract}
Purpose: The purpose of this study is to show that turning Jordan into an economic free zone will lead to a significant increase in foreign investments. This increase, in turn, will lead to an economic growth and to a reduction in the unemployment rate. Jordan is a developing country and any successful investments in the economy sector will have a positive impact on the quality of the social life of its people. This is particularly important now in view of the economic pressure that Jordan is going through as a result of the presence of a huge number of immigrants who have fled the civil wars in neighboring countries.
\end{abstract}

Methodology: This study has utilized the relevant literature by way of evaluating the benefits of establishing economic free zones in Jordan. Many of the findings are based on analyzing statistical information published by governmental institutions in Jordan.

Findings: Jordan offers an attractive investment environment due to the security and stability it enjoys compared with other countries in the Arab region. As such, it has succeeded in establishing new economic free zones through partnership with foreign investors. This has led to a significant increase in the flow of more foreign investments in Jordan. The present study shows that turning the whole of Jordan into an economic free zone will lead to yet a further increase of foreign investments, and hence to more empowerment of the economic sector.

Limitations: The quantitative data available is limited to the years 1999-2007.

Value: The findings of this study can be a point of departure for researchers and economic decision-makers in Jordan to prepare economic plans with the purpose of attracting foreign investments and hence promoting economic growth in the country.

Keywords: economic free zones, foreign investment, economic development, Jordan

\section{Introduction}

Developing countries are facing many economic problems that are expected to worsen over time if no real efforts are exerted towards solving them. Perhaps the most urgent of these problems include high inflation, unemployment, and an increasing deficit in the state budget. These problems are caused basically by the scarcity of natural resources and strict governmental legislations relating to trade and investment, which works to discourage the private sector from investing in economic projects. In order to put practical solutions for these problems, developing countries, especially in the globalization era, are working hard to attract foreign investments. As a developing country, Jordan is placing lots of emphasis on improving its economy and as such its successive governments have been devising strategic plans to attract more foreign investments under the guidance of its supreme political authority. Jordan enjoys unique characteristics which, if sensibly utilized, can render the country a very suitable environment for investment. In addition to political security and stability, Jordan has a strategic geographical location, a qualified human capital, and economic free zones. In fact, the presence of economic free zones is evidence of the serious reformative steps that Jordan has been implementing to attract foreign investments. This study aims to show that turning Jordan entirely into an economic free zone can attract more foreign investments and hence secure more growth in the economic sector.

\subsection{Problem Statement}

The issue that the research addresses is as follows: Turning the whole of Jordan into an economic free zone will 
attract additional foreign investments. This will definitely contribute to the growth of the economic sector in Jordan.

\subsection{Research Questions}

1- What is needed to turn Jordan into an economic free zone?

2- Is Jordan able to secure these needs?

3- How can turning Jordan into an economic free zone attract foreign investments?

\subsection{Research Importance}

The importance of this research is based on underscoring how attracting foreign investments can impact economic growth through reducing the budget deficits and unemployment rates, and increasing the Kingdom's reserves of foreign currencies.

\subsection{Research Objectives}

This research aims to achieve the following objectives:

1- To illustrate how foreign investments can lead to economic growth in Jordan.

2- To emphasize how free economic zones can attract foreign investments.

3- To present the recommendations to Jordan Investment Board (JIB) and Free Zones Corporation to encourage them to devise effective methods for attracting foreign investments.

\section{Methodology}

This research will be conducted by using the statistical reports issued by Jordanian institutions concerned with foreign investments, such as JIB, Free Zones Corporation, and Central Bank of Jordan. The statistical data will be analyzed by calculating the current rate of foreign investments in the existing free zones and subtracting them from the total of foreign investment in the whole country. This is to estimate the volume of expected foreign investments in the event of turning Jordan entirely into an economic free zone.

\section{Literature Review}

Although there is very rich literature on the topic of this study, most of this literature dates back to the $20^{\text {th }}$ century. This has made the researcher face a real problem and accordingly worked hard to find more up-to-date studies. The researcher has managed to find up-to-date studies that are useful to the current study. The studies include:

- Wang (2013) “The Economic Impact of Special Economic Zones: Evidence from Chinese Municipalities."

The study aims to discuss two questions: first, the scope of the benefits of special economic zones, and second the channels of these benefits.

The study was conducted on a sample of 326 municipalities for the period 1978-2007. The results showed that the economic policy bundle of China in terms of private property right protection, tax breaks, and land use policy increased per capita municipal foreign direct investment by $58 \%$ in the form of foreign investments in export-oriented industrial enterprises. Also, special economic zones bring more advanced technology to the host country.

The researcher believes that this article is useful to answer the first question that the present paper raises.

Some believe that the special economic zones are of the tools that the rich countries utilize to have control over the economy of the poor countries.

- Sampat (2010) “Special Economic Zones in India: Reconfiguring Displacement in Neoliberal Order?"

This study aims to reveal some of the legal and political aspects in the Indian scheme to attract special economic zone with a focus on the need to reduce the serious concern of displacement and livelihood. Such concerns haunt thousands of the people who live in rural areas that are scheduled to become large free economic zones. The issues arising from the resistance of peasants to set up a special economic zone in Nandigrem area in west Bengal, Goa, Mumbai, and Maharashtra were discussed in order to provide a comprehensive picture of the reasons conducive to differences in opinion regarding Special Economic Zones in India. The result of the study shows that these zones represent a positive political and economic level of engagement.

- Levien (2011) "Special Economic Zones and Accumulation by Dispossession in India."

The study aims to redesign the theory of David Harvey on forced acquisition of property from the original owner 
through a cultural perspective of a special economic zone in Rajasthan India. The study is conducted by using an eighteen-month ethnographic (cultural) interview and a survey research on an SEZ in the state of Rajasthan. Its purpose is to identify movements, organizations, and people that encourage the establishment of economic free zones in residential and agricultural areas. The results show that these succeeded in preventing the control of economic free zones over agricultural property in India.

- Debaere, et al (2010) "Agglomeration, Backward and Forward Linkages: Evidence from South Korean Investment in China."

This empirical study aims to examine the impact of (upstream and downstream) linkages of foreign investment in the potential investment agglomerations, from the perspective of South Korean investments of China, on the investment type and its benefits for the host country and on the locations of these investments. Data was collected from reports issued by Export-Import Bank of Korea. The study sample consists of all Korean investments in China for the period from 1988-2004.

The results show that these investments have increased significantly and succeeded in establishing diplomatic relations between the two countries. Economic zones include open coastal cities, economic and technological development zones, open coastal areas, technology industry development zones, bonded zones, border economic cooperation zones, and export processing zones. The most attractive locations for Korean investments are Shandong area and Northwest provinces. Also, the results show that forward and backward linkages interacting with the presence of other Korean affiliates in China play a significant role in selecting the location of Korean foreign direct investment in China.

- El-Gohari, and Suthorland (2010) "China's Special Economic Zones in Africa: The Egyptian Case."

The study aims to provide a better understanding of the rapid expansion of Chinese investments in Africa. From an African perspective, these investments are considered of the foreign direct investments. Data is collected from the published statistics of the General Authority for Foreign Investment (GAFI) and cover the period from 1999-2009.

The results show that the creation of special economic zones in Egypt is the outcome of shared efforts between Egypt and China. Both countries have benefited from these zones. In China, the zones have contributed to the increase of the inflows of foreign currencies; they have exceeded two trillion U.S dollars. In Egypt, the Chinese zones have increased employment rates and inflows of foreign currencies, and accelerated technological progress.

- $\quad$ Romer (2010) "Technologies, Rules, and Progress: The Case for Charter Cities."

The study aims to highlight the success factors of economic development in developing countries. The study is based on data that were discussed in a conference which was held in Mexico City in October 2009 entitled: "Challenges and Strategies for Promoting Economic Growth" organized by Banco de Mexico. In view of the themes debated in the conference, the researcher has concluded that reducing poverty in developing countries calls for changing economic and political rules, and introducing new legal and political structures similar to those used in Hong Kong. The conclusions enable the transformation of those rules that obstruct the inflow of foreign investments under the pretext of economic colonialism. Moreover, the researcher points out that Chinese Special Economic Zones are exemplary in promoting economic development for both the investor country and the host country.

\subsection{Theoretical Background}

Researchers, practitioners, and even the states around the globe have shown real interest in the spread of special economic zones. This interest is motivated by the expected benefits of these zones especially for the developing countries that face complex economic problems ranging from poverty, unemployment, continuous deficit in the state budget, to the decline of the exchange rate of the local currency, in addition to many others. Hence, developing countries seek to attract foreign investments in order to support their economy by creating new employment opportunities, reducing poverty, and increasing inflows of foreign currencies.

The nature of the dominant culture, legislations, laws, and tax breaks in a certain country are considered some of the encouraging factors that attract foreign investors (Al-Jaghoub, Al-Yaseen, \& Al-Hourani, 2010; Al-Yaseen, Eldabi, Lees, \& Paul, 2006; Al-Yaseen, Eldabi, Paul, \& El-Haddadeh, 2008; Al-Yaseen, Al-Jaghoub, Al-Shorbaji, Salim, 2010). Foreign investors naturally seek to utilize their surplus funds in profitable projects by establishing special economic zones in several developing countries.

\subsection{Brief description of Jordanian Economic Environment}


Other than phosphate, potash, and the Dead Sea salts, Jordan is poor in raw materials. However, Jordan is considered as an attractive environment for the establishment of special economic zones. Based on the related literature, one can state ten reasons that make Jordan an attractive site for foreign investment. These are the following:

\section{1- Unique and strategic location:}

- Jordan is the meeting point of Europe, Asia, and Africa.

- Jordan is a transportation hub of the Middle East.

- Jordan is an access to the Red Sea through the port of Aqaba, and other ports via neighboring countries.

2- Stable political environment.

- The dedicated and stable leadership of the Hashemite monarchy supported by a democratically elected Parliament.

- $\quad$ Tolerating freedom of belief, speech, press, and private property.

- Firm commitment to private enterprise system.

3- Free market oriented economy.

- Economic policies based on outward-oriented, private sector led approach.

- Ongoing privatization of major state-owned enterprises.

- Significant advances in structural and legal reform.

4- A Package of incentives and exemptions to encourage investments.

- Projects are exempted from income and social services taxes by $25 \%, 50 \%, 75 \%$ for a ten-year period, depending on the location of the project.

- Imported fixed assets are $100 \%$ exempted from customs duties and taxes.

- Imported spare parts for fixed assets are exempted from fees and taxes.

- Additional exemptions from custom duties and income tax are granted for the expansion, modernization, or development of existing projects.

- Hotels and hospitals may purchase furniture and supplies for renewal purposes once every seven years without customs duties.

\section{5- Access to major international markets.}

- Duty and quota free access to the U.S market through the economic free zones.

- Duty free access to EU markets.

- Access to more than 10 Arab countries through the AFTA.

- Bilateral agreements and favorable protocols with over 20 countries.

- Member of the Multilateral Investment Guarantee Agency (M I G A)

6- Free Zones and industrial estates.

- The Free Zone Corporation manages two fully operational industrial parks in Aqaba and Zarqa and two more under constructions in Amman, Sahab Industrial Estate, and the Queen Alia International Airport.

- $\quad$ Five private free zones in Jordan employ over 2500 people in industries such as parks in Amman, Irbid, and Al-Karak.

- Newly opened private industrial parks including Al Tajamouat, Addulayl, and Gateway

\section{7- Qualified and competitive human resources.}

- Abundant workforce.

- Young population: according to the 2015 statistics, the percentage of the Jordanian population between 16 and 40 years old was more than $35 \%$ of the total population.

- According to the same statistics, $87 \%$ of the total Jordanian population is literate.

- According to the same statistics, $17 \%$ of the total Jordanian population have the first university degree, master's degree, and $\mathrm{PhD}$ degree. 
- Highly competitive wage rates.

\section{8- World class infrastructure and communications.}

- State Telephone Company operates on a commercial basis, and it is expected to privatize $40 \%$ of the company in the near future.

- Choice of privately- owned internet service providers.

- Direct Royal Jordanian flights to 47 major cities in Europe, the Middle East, the Far East, North Africa, and North America, served by 26 international airlines.

- Modern highway network.

- Major trucking lines ensuring the movement of raw materials to and from the port of Aqaba, as well as into and from ports of neighboring countries.

- Jordan's port of Aqaba acts as a strategic gateway to Jordan, the developing Red Sea region, and the Middle East as a whole.

\section{9- Attractive investment climate.}

- Tax exemptions on income and social services for up to 10 years.

- Total customs exemptions on imported fixed assets.

- $\quad$ Ease of licensing and registration Procedures.

- Revenues on exports are exempted from income taxes.

- Raw materials imported for use in exported industries are not subject to customs duties.

10- High Quality Life.

- Amenities of modem life are -available and affordable.

- High quality public and private education is provided in Arabic, English, and French.

- Health services in Jordan are of international standards at reasonable rates.

- Developed network in community, active local and international business associations, and cultural centers.

- Traditional festivals, cultural entertainment events, and a wealth of archeological sites.

- Excellent clubs and restaurants.

The above reasons have contributed to increase the volume of foreign direct investment in Jordan by 1.1 billion JD to amount to 18.7 billion by the end of 2013. This has resulted in a decline in the budget deficit of the year 2012 by more than $20 \%$ of GDP. Jordan is now ranked 11 among the Arab countries in foreign direct investment flows, where the foreign direct investment flows increased by 7\% in 2014 (Maqar News).

\subsection{Economic free zones in Jordan}

The number of special qualified industrial zones in Jordan amount now to 4 zones, in addition to two zones that are still under construction. These zones consist of:

1- Dhlail industrial complex: known as Adulayl

2- City industrial clusters: known as Tajamouat

3- Jordan valley project crossing

4- Cyber city

The free zones which are still under construction are:

1- The Hashemite University (Hollywood)

2- Qastal Industry Area

3- Mushatta Qualified Industrial Zone Complex

4- Al- Zay Company for Uniforms.

5- Al-Halabat Qualified Industrial Zone.

6- Resources Company. 
Moreover, there are other three qualified public industrial zones in Jordan. They are as the following:

1- Al Hassan Industrial Estate in Irbid.

2- Hussein Bin Abdullah II Industrial City in Karak.

3- Aqaba Qualified Industrial zone, under construction; (the official site of the Jordanian e-Government). The main challenge the researcher has faced is the lack of new statistics related to the subject. The available data date to 2007. In order to underscore the volume of foreign investments in the qualified industrial zones, table No.1 below shows these investments and their sources.

Table 1. Size of the investment and the registered capital in the qualified industrial zones by nationality for 2007

\begin{tabular}{|c|c|c|c|}
\hline Nation/country & Volume of Investment (US\$) & Percentage of Volume of Investment & Registered Capital (US\$) \\
\hline Emirates & $12,200,000$ & $3.6 \%$ & \\
\hline Pakistan & $37,668,080$ & $11.0 \%$ & \\
\hline India & $19,020,889$ & $5.6 \%$ & $12,977,401$ \\
\hline Taiwan & $77,471,750$ & $22.6 \%$ & $2,551,673$ \\
\hline Turkey & $61,313,559$ & $17.9 \%$ & $6,149,717$ \\
\hline Sri-lanka & $40,786,477$ & $11.9 \%$ & $16,313,538$ \\
\hline China & $17,600,991$ & $5.1 \%$ & $1,326,028$ \\
\hline Jordan & $42,959,436$ & $12.6 \%$ & 988,701 \\
\hline Oman & $2,180,720$ & $0.6 \%$ & 141,243 \\
\hline American & $4,915,493$ & $1.4 \%$ & $2,824,858$ \\
\hline Korea & $6,320,000$ & $1.8 \%$ & 70,000 \\
\hline Britain & $4,472,317$ & $1.3 \%$ & 564,972 \\
\hline Israel & $1,161,355$ & $0.3 \%$ & 70,000 \\
\hline Holland & $3,253,521$ & $1.0 \%$ & 72,034 \\
\hline Switzerland & $7,062,147$ & $2.1 \%$ & 705,000 \\
\hline $50 \%$ Pakistani, & & & 141,243 \\
\hline \multicolumn{4}{|l|}{$50 \%$ American } \\
\hline $50 \%$ Jordanian, $50 \% \%$ American & & & 281,000 \\
\hline $35 \%$ Chinese $65 \%$ British & & & 70,622 \\
\hline $80 \%$ Jordanian, $20 \%$ Chinese & & & 14,124 \\
\hline $2 \%$ Jordanian, & & & 70,621 \\
\hline \multicolumn{4}{|l|}{$98 \%$ Israeli } \\
\hline Jordanian, Emirates, Chinese & 353,107 & $0.1 \%$ & 141,243 \\
\hline British, Taiwan, Jordanian & $3,532,654$ & $1.0 \%$ & 42,373 \\
\hline Total & $342,272,496$ & & \\
\hline Total of Capital & & & $47,861,983$ \\
\hline
\end{tabular}

Source: Ministry of Commerce and Industry of Jordan, QIZ unit.

The table above shows that Taiwan occupies the first rank followed by Turkey in volume of foreign investment in Jordan; 77 million U.S dollar, and 61 million U.S dollar respectively. Israel is located in the last rank: about 1 million U.S dollars. Also, one can note that the diversity of the sources of these investments prevents their withdrawal since they are not owned by one owner $[3,10,12,14]$. The effect of turning Jordan into an economic free zone on foreign investments:

In this section the researcher analyzes the available data in order to estimate the volume of foreign investment if 
the whole of Jordan is to become a free zone.

The needed data for this estimation are the number of qualified projects within the existing qualified economic zones, and the volume of the investment related to these projects for the years from 1999-2007. Table No.2 below shows these data.

Table 2. Number of qualified projects and the volume of investment for the period 1999-2007

\begin{tabular}{llllllllll}
\hline Year & 1999 & 2000 & 2001 & 2002 & 2003 & 2004 & 2005 & 2006 \\
\hline Number of Projects & 2 & 12 & 38 & 43 & 49 & 53 & 40 & 38 \\
Investment Value & 9.1 & 31 & 120.6 & 121.6 & 152.5 & 221.5 & 227.6 & 23007 \\
\hline
\end{tabular}

Source: J I B, Jordan Investment Corporation.

As shown in Table 2, that there was a progressive increase in the number of qualified projects over the stated years with the exception of the years 2005 and 2006. Those years witnessed a sharp decline in the number of projects; however the number increased again in 2007.

\section{Method and Procedures}

The quantitative analysis of data is based on the following approach:

The geographical area of Jordan is 89342 square kilometers. The existing economic free zones occupy 4779 square kilometers. The average of qualified projects is 36 projects.

Relative to space, the number of qualified projects becomes:

$$
\frac{89342 \times 36}{4779}=673 \text { project in the new situation }
$$

Relative to the average of the projects number, number of project becomes:

$36-2$ (the fewest number) $=34$ (increase)

$$
\frac{34}{2} \times 100=1700 \text { (rate of increase) }
$$

$\% 1700 \times 36=612$ project

So, the expected number of qualified projects that are computed according to two styles are almost the same. The average of investment value for the existing qualified projects is 151 .

$151-9.1=141.9$ (increase)

$$
\frac{141.9}{9.1} \times 100=1559 \% \text { (ratio of increase) }
$$

$141.9 \times 1559 \%=2212$ the expected investment value.

This leads us to say that: the greater the number of qualified economic projects, the greater the volume of investment. In this regard, (Al-Yaseen, Eldabi, \& Paul, 2004; Al-Yaseen, Eldabi, Lees, \& Paul, 2006; Al-Yaseen, Al-Jaghoub, \& Al-Salhi, 2011; Al-Yaseen, Al-Gweri, \& Al-Jaghoub, 2007; Tuong, Phi Vinh, 2011) pointed out that Ho Chi Minh City attracted in 2010 three export processing zones and 12 industrial states with a total registered Capital of 2.8 Billion U.SD.

\section{Results and Recommendation}

The results of this study show that Jordan represents an attractive investment environment due to the factors mentioned earlier, and most importantly the security and stability the country enjoys. In this regard, Judeh (2015) told Petra News Agency that Jordan has succeeded in keeping its political security and stability in a turbulent region. Also, the results show that special economic zones have increased the foreign investment flow to Jordan, which has contributed to the economic development in the country. (Al-Yaseen, Hourani, \& Al-Jaghoub, 2012; Taleb, Ghassan \& Shubiri Faris, 2012; Al-Yaseen, Al-Soud, \& Al-Jaghoub, 2015; Al-Yaseen, Al-Soud, \& Al-Jaghoub, 2013; Tuong, 2011; Al-Jaghoub, Al-Hourani, \& Al-Yaseen, 2009) this development has had its impact on the financial and technological sectors. Moreover, the exploratory results show that in case of turning the whole Jordan into an economic free zone leads to a significant increase of foreign investment flows. 


\section{Recommendations}

Undoubtedly, the efforts exerted by his Majesty King Abdullah II have had the main effect on attracting foreign investment to Jordan. The researcher recommends that Jordanian Embassies and Diplomatic bodies should also work hard to encourage the foreign private sector to invest in Jordan. Focusing on the uniqueness of investment environment in Jordan can enable them to attract more foreign investment.

\section{References}

Al-Jaghoub, S., Al-Hourani, M., \& Al-Yaseen, H. (2009). Awareness and acceptability evaluation of using e-government services in developing countries: the case of Jordan, The Proceedings of the 3rd European Conference on Information Management and Evaluation, Gothenburg, Sweden.

Al-Jaghoub, S., Al-Yaseen, H., \& Al-Hourani, M. (2010). Evaluation of awareness and acceptability of using e-government services in developing countries: The case of Jordan. The Electronic Journal Information Systems Evaluation (EJISE), 13(1).

Al-Jaghoub, S., Al-yaseen, H., Hourani, M., Al-Haddadeh, R., \& Salim, M. (2009). E-learning adoption in higher education in Jordon: vision, reality and change. European and Mediterranean Conference on Information Systems (EMCIS), Izmir, Turkey.

Al-Yaseen, H., Al-Gweri, A., \& Al-Jaghoub, S. (2007). IS/IT Investment Appraisal: Prior and Post Implementation Evaluation in Jordanian Firms, International Conference Applied Computing (IADIS), Spain.

Al-Yaseen, H., Al-Jaghoub, S., \& Al-Salhi, N. (2011). Issues and Challenges in Implementing E-Learning Projects in Higher Education: The Case of Jordan. Proceedings of the 10th European Conference on E-Learning (ECEL), UK.

Al-Yaseen, H., Al-Jaghoub, S., Al-Shorbaji, M., \& Salim, M. (2010). Post-Implementation Evaluation of HealthCare Information Systems in Developing Countries. The Electronic Journal Information Systems Evaluation (EJISE), 13(1).

Al-Yaseen, H., Al-Soud, A., \& Al-Jaghoub, S. (2013). Assessing Jordan's e-government maturity level: Citizen's perspective on awareness, acceptability and usage of e-government services. International Journal of Electronic Government Research (IJEGR), 9(4).

Al-Yaseen, H., Al-Soud, A., \& Al-Jaghoub, S. (2015). Assessing Jordan's e-government maturity level: Citizen's perspective on awareness, acceptability and usage of e-government services, In Public Affairs and Administration: Concepts, Methodologies, Tools, and Applications, IGI Global.

Al-Yaseen, H., Eldabi, T., \& Paul, R., (2004). A quantitative assessment of operational use evaluation of information technology: benefits and barriers, Proceedings of the Tenth Americas Conference on Information Systems (AMCIS), New York, USA.

Al-Yaseen, H., Eldabi, T., Lees, D., \& Paul, R. (2006). Empirical post implementation evaluation of IT investment appraisals: Prior operational use and operational use. European Journal of Operational Research (EJOR), 173(3).

Al-Yaseen, H., Eldabi, T., Lees, D., \& Paul, R. (2006). Operational Use evaluation of IT investments: An investigation into potential benefits. European journal of operational research (EJOR), 173(3).

Al-Yaseen, H., Eldabi, T., Paul, R., \& El-Haddadeh, R. (2008). Post-implementation evaluation of IT systems: A close review of practice. In Irani, Z. \& Love, P. E. D. (Eds.), Evaluating Information Systems: Public and Private Sector. Butterworth-Heinemann, Burlington.

Al-Yaseen, H., Hourani, M., \& Al-Jaghoub, S. (2012). Success and Failure of eLearning Projects: Alignment of Vision and Reality, Change and Culture. Journal of Emerging Trends in Computing and Information Sciences (JETcis), 3(2).

Anas, R., Al-Soud, H., Al-Yaseen, S., \& Al-Jaghoub, H. (2014). Jordan's e-Government at the crossroads. Transforming Government: People, Process and Policy (TG:PPP), 8(4).

Awad, T. (2009). Jordanian Qualified Industrial Zones, Performance, Economic Effects and future prospects.

Debaere, P. et al. (2010). Agglomeration, Backward and forward Linkages: Evidence from South Korean Investment in China. Canadian Journal of Economics, 43(2).

Eldabi, T., Paul, R., \& Sbeih, H. (2003). Operational Use Evaluation / Post Implementation Evaluation of IT. 
United Kingdom Academy of Information Systems (UKAIS), 2003, Warwick, UK.

El-Gohari, A., \& Suthorland, D. (2010). China in Special Economic zones in Africa: The Egyptian case. Global Economic Recovery.

Farole, T. (2011). Special Economic Zones in Africa. The International Bank for Reconstruction and Development / The World Bank.

Judeh, N. (2015). Security, Stability in Turbulent Region. Petra News Agency 2015.

Levien, M. (2011). Special Economic Zones an Accumulation by Dispossession in India. Journal of Agrigan Change, 11(4), 454-483.

Romer, P. (2010). Technologies, Rules, and Progress: The Case for charter cities, Center for Global Development. Retrieved from https://www.cgdev.org/content/pulications/detail/1423916

Sampat, P. (2010). Special Economic Zones in India: Reconfiguring Displacement in Neoliberal order? Journal of City and Society, 22(2), 166-182.

Taleb, G., \& Shubiri, F. (2012). Capital Structure Decisions and Debt Maturity Structure: An Empirical Evidence from Jordan. The Journal of Commerce, 3(4).

Tuong, P. V. (2011). Development of Special Economic zones, Industrial States, Ports, Metropolis and Alternative Roads in the Greater Ho Chiming City, Report No.6, Bangkok Research Center.

Wang, J. (2013). The Economic Impact of special Economic Zones: Evidence from Chinese Municipalities. Journal of Development Economics, 101, 133-147.

\section{Copyrights}

Copyright for this article is retained by the author(s), with first publication rights granted to the journal.

This is an open-access article distributed under the terms and conditions of the Creative Commons Attribution license (http://creativecommons.org/licenses/by/4.0/). 